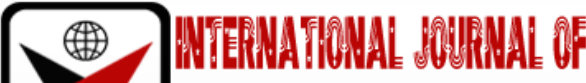

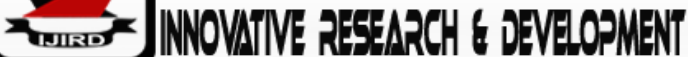

ISSN 2278-0211 (Online)

\section{Incidents of Sexual Violence against Females in Halima Bashir's Tears of the Desert: A Memoir of Survival in Darfur}

\begin{tabular}{|c|}
\hline Dr. Ehinmowo, Onuw Chiagoalim \\
Assistant Lecturer, Department of Languages And Literary Studies ( English Literature ), \\
Babcock University, Nigeria \\
Dr. Iguanre, Solomon \\
Senior Lecturer, Department of Languages And Literary Studies (English Literature ), \\
Babcock University, Nigeria \\
Dr. Adebua, Babatunde \\
Senior Lecturer, Department of Languages And Literary Studies ( English Literature ), \\
Babcock University, Nigeria
\end{tabular}

\begin{abstract}
:
Issues of sexual violence across the globe are alarming. Rape and gang rape of vulnerable women and girls have become commonplace in many countries. Victims experience physical, emotional and psychological abuse. This paper examines sexual violence against women and girls as recorded in the novel Tears of the Desert: A Memoir of Survival in Darfur. The paper attempts to identify the causes and consequences of sexual violence against females in the selected novel. This study employs feminism and New Historicism as its theoretical framework. The findings revealed that sexual violence is an outcome of a larger problem of gender inequalityand that rapist use rape as a weapon to instill fear and humiliate vulnerable women and girls. Thestudy further reveals that gang rape of women and girls during wartime situations has been used as war tactics. Females have been regarded as one of the legitimate spoils of war.
\end{abstract}

Keywords: Sexual violence, rape, gang rape, female genital mutilation, feminism, new historicism

\section{Introduction}

This paper examines instances of sexual violence against females in Halima Bashir's Tears of the Desert: A memoir of Survival in Darfur. The paper explores the shocking, devastating and heart- breaking atrocities committed against women and examines how rape was used as a weapon of war in Sudan. This essay will limit the use of the term rape to the incidences where women and girls are penetrated through the vagina. This study also seeks to expose child sexual abuse (rape) as recorded in the novel; appraise the psychological trauma effects on the victims of sexual violence and scrutinize the consequences of sexual violence on Black African Sudanese females in the novel.

\section{Background to the Study}

Sexual violence refers to any action that pressures or coerces someone to do something sexually that they don't want to do. It includes unwanted kissing or touching; rape or attempted rape; and or sexual contact with someone who is drunk, drugged, unconscious and unable to give a clear and informed yes or no.

Sexual violence is any sexual activity that takes place when consent is not freely given. Sexual violence occurs when a perpetrator commits sexual acts without the victim's consent, either because the victim is unwilling to accept the sexual advances or the victim is sick, disabled or the victim is too young (in the eye of the law) to give consent. It includes vagina penetration and even non-vagina penetration like unwholesome touching of the victim's body. It also includes other sexual assaults such as oral and anal penetration of the victim (without the victim's consent). According to Brownmiller, sexual violence causes serious health challenges and research has shown that many cases of sexual violence go unreported, mainly because the victims are ashamed, traumatized, embarrassed or threatened with further harm. Usually also, victims are afraid to report to the Police; and it is important to note that sexual violence is an outcome of a larger problem of gender inequality. (p14)

World Health Organisation (WHO) defines sexual violence as: Any sexual act, attempt to obtain a sexual act, unwanted sexual comments or advances otherwise directed against a person's sexuality using coercion, by any person, regardless of their relationship to the victim, in any setting, including but not limited to home and work" (WHO,2007). Furthermore, sexual violence includes sexual harassment, female genital mutilation and forced vagina and anal penetration.

Furthermore, sexual violence, by extension, includes other forms of sexual assault involving a sexual organ and coerced contact between the mouth and penis, vulva or anus. It includes rape, defined as the physically forced or otherwise 
coerced penetration of the vulva or anus with a penis, other body part or manipulated object. Sexual violence, particularly rape and gang rape, is used to dishonour, degrade, shame, destroy, terrorize, intimidate and it is an attack on the integrity of females in any given society. According to Kaira, G and Bhugra, D., sexual violence is regarded as the most violent, humiliating and brutal offenses inflicted on women and children. Sexual violence against women is often as a result of unequal power equations between men and women (p. 244-249).

The culture of impunity surrounding sexual violence and rape has become a national emergency in most countries. Rape is defined as having an unlawful carnal knowledge of a woman or girl without her consent. Rape is a sexual event that occurs without the other person's consent and which involves the use of force. Usually, it involves the penetration of the victim's vagina, mouth or rectum either by a penis, fingers or an object. Rape is said to occur between a man and a woman or girl in any of the following circumstances: against her will; without her consent; with her consent when the consent is obtained by putting her in fear of death or of hurt. (Section 258 - under the Criminal laws of Lagos State. Nigeria). That is, a victim may consent to rape under duress or undue influence. Rape can be under forced penetration or resisted penetration. Forced penetration is where the victim physically resists yet the aggressor persists. Unresisted penetration can occur when the victim is drugged or have been given substance meant to demobilize the victim.

In addition, rape can be categorized as follow:

- $\quad$ Substance - induced (drugs)

- $\quad$ Force (force penetration)

- Incestuous

- Those familiar with the victim (neighbours)

- Strangers (unfamiliar with victim).

Furthermore, rape is a criminal act that has become a pressing issue all over the world. Rape, gang rape, other violent and forced sexual acts against females is a violation of their dignity; their rights as humans; and it is a violation of international rights laws. Rape has led many victims to make horrible and irrational decisions such as murder or suicide. Many females who were raped often battle with sexually transmitted infections, unsafe abortions, vesico - vaginal fistulae (VVF) which can have permanent damage, first to the gap between the vagina and the urethra, and then the uterus. Also, victims may suffer depression, emotional and psychological trauma. Rape and other forms of sexual violence, such as gang rape, affect social, physical and psychological well-being of the victims and usually result in total loss of self-esteem.

A United Nations' statistical report compiled from government sources showed that more than 250,000 cases of rape or attempted rape were recorded by the Police annually. Furthermore, rape is one of the most common crimes against females. This is because rape is used to humiliate, demoralize and dehumanize victims for selfish reasons and, sometimes, for social, economic and political gains. Men use rape as a weapon to instill fear, humiliate, subdue, take advantage of vulnerable women and girls who are mostly weaker and defenseless. Rape damages the victims and leaves scars which are physical, emotional and psychological. Global estimates published by WHO indicate that about 1 in 3 (35\%) of women worldwide have experienced either physical and / or sexual intimate partner violence or non - partner sexual violence in their lifetime. Sexual violence is a serious public health issue and has a profound short and / or longterm impact on the physical and mental health such as an increased risk of sexual and reproductive health problems.

Furthermore, it is reported that a girl is raped every 20 minutes in India. According to the National Crime Records Bureau (NCRB), 2013 annual report; 24,923 rape cases were reported across India in 2012. Moreover, according to the Nigerian Tribune of 12th September, 2019 (World News Column), in Brazil, four girls under 13 are raped every hour and every two minutes the Police receive a report of violence against women and girls. Brazil, a country which is home to over 200 million people, is among the most dangerous places on earth to be a woman. (p33). In South Africa (SA), rape is regarded as SA's most prevalent sex crime. The rate of sexual violence in South Africa is among the highest in the world. During 2015/2016, there were 51, 895 crimes of sexual nature reported to the South African Police Service. World Health

Organisation research reported that between 61 percent and 77 percent of women and girls were raped in Liberia during the war. Of rapes documented by the United Nations (UN) in Liberia in 2015; almost 80 percent of victims were under the age of 18, including at least five girls under the age of five.

In Nigeria, Folarin, a journalist with The Punch on August 2, 2019; reported that the course of justice was served on a 52-year-old herbalist, Jacob Alonge, who was sentenced to 21 years in prison for raping and impregnating his daughter - Gift - at their home in Ososo village, in the Akoko-Edo area of Edo State, Nigeria (p13). Furthermore, Afeez Hanafi of The Punch reported that Justice Muslim Hassan of a Federal High Court in Lagos sentenced a 58-year-old farmer, Yesiru Onajobi, to 10 years imprisonment for defiling and impregnating his teenage daughter. (Sept. 28, 2019. p33). The judge, who noted the rising wave of rape in society, ordered that the convict (Yesiru Onajobi) should serve the term without an option of fine. On Friday, Oct. 25th 2019, Odita Sunday and Yetunde Ayobami Ojo of The Guardian reported that a former School Supervisor at Chrisland International School, Lekki, Mr. Adegboyega Adenekan aged 47, accused of defiling a two-year-old has been sentenced to 60 years imprisonment by Justice Sybil of Lagos Sexual and Domestic Offences Court, Ikeja. Lagos. Nigeria. Also, in another development, Afeez Hanafi of The Punch, Nigeria, on February 3rd 2019 reported that the 2018 Report of the Domestic and Sexual Violence Response Team (DSVRT) of the Ministry of Justice, Lagos State, Nigeria, has shown a 134 percent increase in cases of rape, defilement and domestic violence handled by the agency, compared to the previous year (p.5).

Moreover, Chidiebube Okeoma of The Guardian of Thursday, August 8, 2019, reported that operatives of the Special Anti-Robbery Squad, Imo State Police Command, Nigeria, have arrested Onyekwere Umunna, for allegedly defiling a seven-year-old girl (pp4,5). Also, Odita Sunday of The Guardian reported that the Police, in Lagos State have arrested a 34 - year - old man, Innocent Ifunayachi for allegedly drugging and raping a teenage daughter of his host. The suspect was 
said to have visited a family friend, met his host, 14-year-old daughter eating noodles and laced the meal with dried Marijuana when the teenager left her meal to get him a drink. Similarly, the Police, in Lagos, arrested 24-year-old Dayo for allegedly raping a 13-year-old girl and threatening to do same to her younger sister. (The Guardian, Sept 16, 2019). Furthermore, in a major onslaught against rapists, operatives of the Lagos State Police Command have arrested two men who allegedly raped their 19 year and 15-year-old daughters. The 19-year-old alleged that her step father, Akin Olatilu, has been sexually abusing her since she was 14 years old. Again Yisah Showunmi, 68 years, was alleged to have been having carnal knowledge of his 15-year-old daughter since she was 12 years. The young girl further alleged that when her two friends, ages 15 and 16, came to stay in their house, her father (Yisah Showunmi) also had sexual intercourse with them (The Guardian, July 8, 2019). Inemesit Akpan-Nsoh of The Guardian also reported that Joseph Sunday of Obot Idim Ibesikpo, in Akwa - Ibom State, Nigeria, has been nabbed by the Police for allegedly raping his two daughters aged 9 and 13 years. The suspect, it was gathered, has been having carnal knowledge of his daughters for 3 years. The suspect, who confessed to the crime, said he wanted to test if his manhood was still functioning well.

Also, an in-depth UN Study in 2006 suggested that at least one in every three women around the world has experienced sexual violence at some time. Worthy of note, too is the report by the United Nations (UN) former Special Rapporteur on Torture, Professor Kooijmans, that rape and other forms of sexual assault against women and girls constitute a violation of the dignity and the right to physical integrity of humans. He concludes that rape is torture that is both physical and psychological and it is a crime, just like murder and, in some cases, women and girls are infected with sexually transmitted diseases, including HIV/AIDS, or may be raped to death. In 2016, the United Nations Organisation Stabilization Mission in the Democratic Republic of the Congo (MONUSCO) verified 514 cases of conflict related sexual violence. The victims included 340 women, 170 girls, three men and one boy. During the same period, the United Nations Population Fund (UNFPA) reported 2,593 cases of sexual violence in conflict-affected provinces (Guterres, Antonio 2017). In addition, in 2016, the United Nations Mission in South Sudan (UNMISS), documented 577 incidents of conflict-related sexual violence, including rape, gang rape and sexual slavery. The survivors included 57 girls, several of whom were below 10 years of age, with two being less than one year old. In Sudan (Darfur), sexual violence has devastated the lives and livelihoods of women and girls over the years. Still, in 2016, the African Union - United Nations Hybird Operation in Darfur (UNAMID) documented 100 incidents of conflict-related sexual violence affecting 222 victims, specifically 102 women, 119 girls and one boy. These incidents included rape, gang rape, attempted rape, abduction for the purpose of sexual assault and sexual harassment (Guterres, Antonio 2017). Furthermore, The United Nations, in a recent research, identified fortysix parties as credibly suspected of committing rape or other forms of sexual violence (UN 2017).

Also worthy of note is that rape of women and girls has long been an endemic feature of war. Rape or gang rape of women and girls, especially during wartime, is an attack on the integrity of individual women as well as their communities. Sexual violence in wartime is usually penetrated to cause humiliation, damage and destroy the psyche of the 'enemy'. This is especially so that wartime rape is regarded as one of the legitimate spoils of war and it destabilizes communities and fuels displacement of women and girls. Also, fear of rape can cause women and girls to flee their communities. Gang rape of women and girls during wartime situations has been used as war tactic to erode family and community structures.

According to March bank and Letter by (2007) in their book Introduction to Gender: Social Science Perspectives, "All rape is an experience of power, domination, degradation and humiliation'. The rapist usually takes a position of power which allows the rapist to torture, attack and brutalize the victims whom the rapist deems as inferior. (p56). Furthermore, Susan Brownmiller, an American feminist journalist, who wrote the book Against Our Will: Men, Women and Rape argues that "Rape is a conscious process of intimidation by which all men keep all women in a state of fear." (1975). Also, Brownmiller postulates that men use rape as a means of perpetuating male dominance by keeping all women in a state of fear. Brownmiller believes that all men benefit from the culture of rape. According to Brownmiller, rape is the main source of women's oppression. Therefore, to overcome oppression, women must divest men of the power of rape, because when men discovered they could rape, they proceeded to do it (14). Brownmiller concludes that it is rape and the threat of rape that is responsible for the subjugation of women. In Tears of The Desert: A memoir...in Dafur, young school girls are raped and that the school is targeted to instill the worst possible terror against Sudanese women and girls. (p278).

Darfur is a region in present day Sudan and it shares borders with Chad, Libya, and Central African Republic. It is a region in the western part of Sudan and has a population of about seven million people. Darfur is home to different ethnic groups, including Blacks in the western part and Arabs in the northern part.

\section{Synopsis of the Novel}

This is an autobiographic novel by Halima Bashir, a medical doctor, born in rural Sudan from very poor beginnings. Sudan soon became a war-torn nation where victims of various abuses including rape and genital mutilation became her patients. Hearing their stories first-hand, Halima decided to speak out and write about this inhumane situation of things. Her decision to speak out led to threats to life and imprisonment. This autobiography, Tears of the Desert, tells of the life of Halima Bashir in the Darfur region of Sudan. The story paints a vivid picture of her childhood, growing up in her village, a rural community among her Zaghawa tribe in the Sudanese desert.

Halima is the daughter of an educated cattle herder, prosperous enough to own a car. Her father sends her to a city secondary school at Hashma (Darfur), where she excels as a student. At the secondary school, Halima has issues with arrogant and abusive Arab school mates and teachers who are unfair in dealing with school girls' scuffles.

In this text, Halima gives a vivid description of the violence on the black African tribes of Darfur by Sudanese minority Arab (Janjaweed) with the support of the then ruling Military Government of Sudan. The text further describes the untold suffering, harrowing, shocking and the unforgettable tragedy of the effects of violence on black Africans in Sudan, especially the sexual violence against women and girls. 
The text is divided into two sections. The first section is about her growing up in her village among her Zaghawa tribe, where they share a lot of love among one another, everyone being their brother's keeper. The second part of her memoir relates her move to the city, where she attends post-primary school, her university days and her work as a medical doctor. Bashir tells of school girls' scuffles that lead to physical fights and lack of support from teachers. She also tells how, as a medical doctor, she treats both Arab militia and black rebels (as against Government instruction of abandoning and reporting black rebels with gunshot wounds). Bashir describes vividly the mass rape of teachers and forty-two (42) school girls (some as young as eight years) on a single day, in their classrooms by the Janjaweed. She describes the actions of government officials surrounding the school and firing on parents trying to rescue their daughters. She treats these traumatized school girls in the hospital.

Government officials later take her (Halima) away from the hospital for two days for granting interview with UN officials on the rape incidents. They, (Government officials), then beat and gang rape her before being set free. She returns to her family, but her village is also attacked by the Janjaweed.

Bashir concludes the novel, describing how she flees Darfur with the assistance of a paid agent and her struggles when she arrives London to obtain asylum as a refugee in the United Kingdom (UK).

\section{Objectives of the Study}

The objectives of the study are to:

- Examine instances of sexual violence against black African Sudanese women and girls (females), as detailed in the selected text.

- $\quad$ Expose cases of child sexual abuse (rape) in the text

- Explore how rape (gang rape) was used as a weapon of war in Darfur, Sudan.

- Appraise the psychological trauma effect on the victims of sexual violence during the act

- Scrutinize the consequences of sexual violence acts on black African Sudanese women and girls (females) in the selected text.

\section{Methodology}

This article employs qualitative methodology and uses the descriptive research design to uncover the various acts of sexual violence against women and girls as depicted in Halima Bashir's Tears of the Desert: A memoir of Survival in Darfur.

\section{Theoretical Framework}

This study adopts Feminism (third wave feminism) and New Historicism as its theoretical framework. Feminism is concerned with women issues, their emancipation, their experiences, equality of the sexes and equal rights and opportunities for women and men. Feminism tries to bring about change in the way women are perceived and treated in the society. It tries to discourage discrimination, humiliation, perceived injustice against women and focuses its attention on the emancipation of women and girls. According to Elizabeth Fox-Genovese in her essay, "Placing Women's History in History", feminism places women at the center of history by recognizing their peculiar roles and contributions in the shaping of history (p29).

Feminism has been categorized into different waves, namely: First wave feminism (Martha Lear); Second wave feminism (Betty Friedan); Third wave feminism (Rebecca Walker) and Fourth wave feminism (associated with use of social media). Also, there are different strands of feminism, namely: Liberal feminism (Mary Wollstonecraft); Marxist or socialist feminism; Radical feminism; Cultural feminism; Eco-feminism; Gender critical feminism; Post-modern; Post structuralist; Black feminism and various African variants of feminism, such as Womanism (Okonjo-Ogunyemi); Motherism (Acholonu, C); Stiwanism (Ogundipe-Leslie, 0.); Snail Sense feminism (Akachi- Ezeigbo), feminism with a small $\mathrm{f}($ Emecheta, B.) and Negofeminism - Nnaemeka,0. (Sotunsa, 97).

Third wave feminism is a period of feminist activity and thought that began in the United States in early 1990s. It aims to be intersectional by examining interconnected structures of society that include race, ethnicity, class, religion, gender, nationality, sexual orientation and concludes that, all these are significant facts when discussing feminism. Intersectionality is also used to describe the idea that women experience layers of oppression caused by race, gender, class, sexual harassment. Violence against women and girls, including rape, domestic violence and sexual harassment was a central issue in third wave. Third wave feminism redefined women and girls as assertive, powerful and in control of their own sexuality.

Furthermore, third wave feminism is credited to Rebecca Walker who responded to Clarence Thomas appointment to the Supreme Court with an article in MS Magazine, decrying the appointment. This is because Anita Hills (a victim of sexual harassment) had appeared before an all-white, all-male Senate Judiciary Committee in a televised testimony in 1991 to protest that Clarence Thomas has sexually harassed her.

Tears of the Desert: A memoir of Survival in Darfur has all the tenets of third wave feminism, particularly the issue of sexual violence against women including female genital mutilation, gang rape and sexual harassment.

New Historicism emerged in the early 1980s as a literary theory. It is a literary theory based on the idea that literature should be studied and interpreted within the context of both the history of the author and the history of the critic. It acknowledges that a work is not only influenced by its author's times and circumstances but, that the critic's response to the work is influenced by his environment, beliefs and prejudices. In essence, new historicism aims at understanding intellectual history through literature and literature through the cultural context surrounding the historical event. Stephen Greenblatt, an English Professor is the acknowledged initiator of New Historicism. 
According to Peter Barry, it is crucial to read both literary and non - literary texts of the same period in order to make a new historicist criticism. They emphasize the notion that historical values change over time. Also, New Historicists teach that history can be taught and understood from several different platforms. Therefore, students can see themselves in such stories. (p172). More so, new historicism posits that literary works are based, both on parallel readings of literary and non - literary texts like newspapers, magazines articles and editorials.

\subsection{Basic Tenets of New Historicism}

- It is based on the idea that literature should be studied and interpreted within the context of both the history of the author and the history of the critic.

- Literary and non - literary texts circulate inseparably and based on parallel readings of both.

- It is based on the analysis of cultural, historical, social interaction of the period in which the literary work was written.

- It acknowledges that a work is not only influenced by its author's times and circumstances but, that the critic's response to the work is influenced by his environment, beliefs and prejudices.

\subsection{Types of Sexual Violence as Recorded in the Selected Texts}

Sexual violence is a common phenomenon that occurs all over the world. Sexual violence is an abuse that is mostly targeted against females. It takes the form of Female Genital Mutilation (FGM), rape, gang-rape, organized rape in wartime and rape of children.

Female Genital Mutilation (FGM): Female genital mutilation otherwise known as female circumcision means piercing, cutting, removing a woman's or young girl's external genitals (Clitoris), either for cultural reasons or for reducing sexual pleasure of the victims. FGM is a deeply entrenched cultural practice in most African countries and a leading form of violence against women and girls. According to World Health Organisation, female genital mutilation constitutes all procedures which involve the partial or total removal of the external female genitalia or other injury to the female genital organs, whether for cultural or any other non- therapeutic reasons (WHO, 2001). This procedure is usually done, using special knives, scissors, razors or any sharp objects and mostly done by elderly women in the villages or traditional birth attendants. However, FGM is medically risky and many women and girls die from the wounds. It is a traditional practice that is harmful and one that has outlived its usefulness. This form of sexual abuse occurred severally in the selected novel. Girls were coerced, seized forcefully, cut under unhygienic conditions, using the same unsterilized instruments and carried out by local women, with no medical training as midwives or birth attendants. The tools used include unsterilized knives, scissors, clippers and hot objects. In the selected novel, Bashir recounts how she was circumcised:

.....early the next morning, the taihree arrived - the traditional circumcision woman of our village. She had no formal training, but she did all the womanly things ......the taihree prepared her instruments - her razor blade, bowls of water and clothes. I felt a
stab of panic.
...p.55.

- $\quad$ Rape: This is an act of sexual violence that involves having carnal knowledge of males / females without their express permission. It is an act of sexual assault that involves sexual vagina penetration without the other person's consent. It may be carried out by physical force, undue influence, abuse of authority, taking undue advantage of children and / or those who are unconscious, incapacitated or those who are unable to resist. Rape is also considered as a pathological assertion of power over a victim. Usually, rape is more often committed by a male against a female. Many rapists commit this heinous crime with the intent to control through fear; to cause pain; to punish; to gain revenge and also to prove sexual prowess.

In the selected novel, there was sexual abuse against females. School girls and their teachers were targeted and abused sexually in school. Bashir documented that the youngest of the girls was just seven years old and the eldest thirteen. And that the victims were traumatized schoolgirls along with their shocked and grieving parents. (p213). Bashir describe the incidents as below:

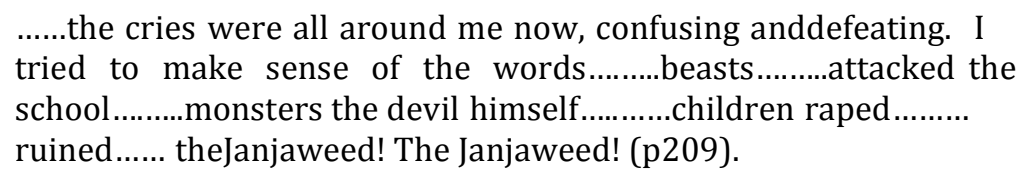

- Gang rape: This is a form of rape that occurs when two or more persons are involved in the rape of the same victim. It is the rape of the same victim by two or more perpetrators. Ethnic conflict and wars witness a lot of gang rape. Bosnia wars, during the 1990s, saw a similar campaign of gang rape. In the 2000s, war-torn countries of Afghanistan, Syria, Pakistan and, Sudan reported high rates of gang rapes by government soldiers and militias. In Sudan particularly, allied militias raped women and girls as part of a campaign to win the war between white minority Arabs and the black African Sudaneses. According to the United Nations Secretary-General, Antonio Guterres, "Conflict related sexual violence is now widely recognized as a war crime that is preventable and punishable. The United Nations Security Council has played an important role in the past decade by passing successive resolutions that emphasize accountability for perpetrators and services for survivors." (UN Report, 2017).

In the selected novel, Halima Bashir gave a vivid report of how she was gang raped by 'three men dressed in scruffy kaahaki uniforms'. She rues it in detail: 
............they took me to the far side of the village, to a military camp....the soldiers dragged me out.........istepped into the room and without warning the beating began......I was kicked hard in the stomach.......i fell to the floor....bring some rags......we need to stopUp this black bitch's mouth i know what is coming now. It is rape and death....that night they come for me.........lie back and take it like the black slave you are the three of them took turns raping me, one after...the other. Once the third one had finished, they started over again... (p.223 227).

\subsection{Causes of Sexual Violence against Females in the Selected Novel}

Some of the causes of sexual violence as explored in Tears of the Desert include cultural practices, Sexual Abuse (Gang Rape of Women and Girls) and how rape was used as a weapon of war in Darfur.

War Situation

War is a situation or a period of fighting between countries or groups of people. War situation is a state of armed conflict between states, governments, groups and so on. In a war situation, sexual violence is deliberately employed as tactic to terrorize women and girls. Sexual violence in a war situation flourishes under a climate of impunity. It is important to note that State forces are more likely than rebels to be perpetrators of sexual violence and in most cases women and girls are treated as wages of war. United Nations reports document that pro - government militias in South Sudan were allowed and even told to rape women in lieu of payment of government wages. Rape in war is common and damaging to the whole community. War situation is among the causes of sexual violence in the selected novel.

\subsection{Cultural Practices}

Cultural practices refer to the manifestation of a culture, especially as regards a particular ethnic group. Cultural practices are shared perceptions of how people behave in a culture. Cultural practices against women and girls in Africa are harmful. These cultural practices include gender discrimination in homes and workplaces, early marriage, sexual harassment and female genital mutilation. These harmful practices against women and girls have been sustained by cultures and patriarchy. Sexual violence is still very rampant and is known to shatter the lives of women and girls affected as well as undermining their development and gender equality. In the selected text, Bashir provides instances of harmful cultural practices of girl-child being circumcised (FGM), early marriage of young girls, rape and gang rape of women and girls.

\subsection{Sexual Abuse (Mass Rape of Women and Girls)}

Sexual abuse and assault, in all its forms need to be combated. The atrocities perpetrated against victims who are usually women and girls are heart-breaking. Sexual abuse is an act of violence that can be perpetrated by parents, care givers, acquaintances and strangers and in a war situation by war-lords, rebels and militias. Mass rape of women and girls is often used as a method of war rape, which is a form of attack / 'victory' on the enemy camp. In the selected text, Bashir describes how she was gang raped by government soldiers while in their custody at a military camp. She gives a detailed account of how she was raped repeatedly by these men.

\subsection{Rape Used as a Weapon of War in Darfur}

Rape has been used as a strategy and weapon of war in many armed conflicts. It has been used as a tool of ethnic cleansing. War has a devastating effect on everyone in the communities, particularly women and girls. In most war time situations, rape is often used on a massive scale by the war lords and the militias. Rape, as a weapon of war, was used as a means of genocide in Rwanda, as a form of ethnic cleansing between Bosnia and Herzegovina and even in present day Nigeria (in the prolonged Boko Haram disturbances in Northern Nigeria); women and girls are captured, raped and intentionally impregnated. In most of these war-torn countries and in Tutsi ethnic groups in Rwanda and Burundi, women and girls are raped by HIV - infected men. According to The United Nations (UN) Human Rights Council, systematic rape and military sexual slavery are crimes against humanity, punishable as violations of women's human rights (UN 2006). UN's Fourth World Conference on Women specifies rape by armed groups during wartime as a war crime (UN, 1995).

\subsection{Feminist Disposition in Tears of the Desert: A Memoir of Survival in Darfur}

Halima Bashir's Tears of the Desert is a feminist book. This book is a memoir in which Bashir gives an historical account of her life in Darfur with specific timelines and recounting her memories, feelings and emotions about the sexual violence she and other females experienced in her home land Darfur. Bashir, specially wrote from a feminist perspective. The text supports the feminist goals of social equality of the sexes and campaigns for reforms on issues such as domestic violence, sexual harassment and violence.

Feminism reflects perspectives of scholars that portray issues of violence against women, women subjugation, abuse and deprivation. It is about the view that women and girls should have equal rights and opportunities as men. It is the struggle for women liberation, sexuality and freedom from sexual harassment and assault.

- Tears of the desert: A memoir of Survival in Darfur exposes the evil of cultural practice as a militating and inhibiting factor against women in Africa, when she recounts her experiences and the pain she suffered during her own female genital mutilation (FGM). Also, she bemoans the torture and child sexual abuse that girls as young as eight years suffered during the rape of young female pupils in school. She also gives livid illustrations on the gang 
rape, she endured in the hands of government officials. The violence may simply dovetail into the categories examined below.

\subsection{Female Genital Mutilation}

This is a procedure performed on women and young girls in many African countries that is supposed to usher young girls into womanhood. It involves the forceful removal of female genitals for the sole reason of initiating a young girl into womanhood and reducing promiscuity. Unlike the male circumcision, it has no health benefit and is not performed for medical reasons. The text laments that all girls (as young as eight) in the Zaghawa tribe are circumcised as it is the general belief that circumcision is supposed to mark the passage from girlhood to womanhood. More worrisome is the fact that the traditional circumcision practitioner has no formal training. Bashir captures it as follows:

...... with the first slash of the razor blade, A bolt ofagony shot

through me like Nothing 1 had experienced. I let out a bloodcurdling Scream, and as l did so l starting kicking and fighting to get free but as 1 did so 1 Heard the women outside start making the illil Aye - aye - aye aye - aye- aye - aye -aye - aye. it was supposed to be a celebratory chant (56).

Female genital mutilation on women and girls is done to prepare them for marriage and adulthood. Its cultural significance is supposedly to maintain girls' chastity, ensure premarital virginity, enhance sexual pleasure for men and ensure marital fidelity by reducing the victim's desire for extra marital sexual acts. Supposedly by so doing, it keeps women from premature death. However, Bashir explains the faulty unhygienic procedure. She says:

......by the time the taihree had finished, I have been completely sewn up, leaving only a tiny little hole. Everything else was gone. I was half - delirious. .......we all knew of girls who had died during their cutting time. Sometimes, a vein was cutduring the butchery, and no one could stop the bleeding. At other times, a girl's wounds would become infected, and she would die a long,lingering death....... (p. 57-59)

\subsection{Attack on the School and Child Sexual Abuse in the Selected Novel}

Child sexual abuse has become an issue globally. It does occur in a variety of settings, at home, school, among family members, adult abusers or in a war situation. The American Psychological Association states that children cannot consent to sexual activity with adults. Bashir recall how school girls were abused sexually in their classrooms by the 'The Janjaweed'.

She captures it graphically:

... the youngest of the girls was just seven years old, the oldest thirteen.........it was like a band of wild animals just jumping on us and forcing us to the floor. All around me girls were being raped, regardless of their age...... we have come here to kill you! .......you are worse than dogs! Either we kill you. (p.215-217)

Bashir continued the vivid description of the sexual attack on school girls as follows:

.....forty - odd girls had been brought to the clinic But l knew they were more rape victims than that... Parents were so ashamed that they had taken their daughters home and would be treating them privately with traditional cures.....it was a sad fact in our culture that rape victims were seen as being damaged goods. Their lives destroyed by the evil that had happened to them. (p216).

\subsection{Sexual Harassment and Gang Rape}

Sexual harassment is unwelcome sexual advances; request for sexual favour or other unwholesome physical conduct for the purpose of violating the dignity of a person while creating an intimidating, hostile behavior that can involve forced sexual activity. Most times, sexual harassment preludes rape and or gang rape. Bashir gives a vivid description of how she was gang raped:

...Bring some rags.... We need to stop up this blackbitch's mouth. the door is slammed shut. I hear

a key turning in the lock. I know what is coming

now. It is rape and death, rape and death. that

night they came for me......it is three rangers...Lieback and take it

like the black slave you are .... My

God, She is tight...Real tight The three of them

took turns raping me, one after the other. Once

the third had finished, they started over again..... (pp. 225 - 227). 


\subsection{Consequences of Sexual Violence on Females as Depicted in the Novel}

Sexual violence is a crime which has devastating consequences on the victims. The dehumanizing consequences of sexual violence against females in the textual analysis are better imagined than experienced. It entails emotional, psychological traumas, physical separation from loved ones and death of loved ones. The consequences go beyond the victims as it affects the whole family, friends, their significant others and the community. All are negatively affected as victims usually feel shame, anger, anxiety, low self-esteem, disillusioned and are withdrawn from relationships, develop depression and, Post - Traumatic Stress Disorder (PTSD) and may attempt suicide.

Also, it is important to note that these consequences affect developmental outcomes as they may prevent women and girls from attaining their full potentials in all of their life's endeavors; may affect their health negatively, deny them employment opportunities and may affect their ability to contribute to the development of their societies. Some of the consequences are examined below.

Psychological Trauma Effects: Sexual violence causes great psychological harm. The psychological reactions of victims include feelings of rage, shame, fear, guilt, self-blame, sadness, hopeless, confusion or a combination of all. Also, there could be a long-time disruption of sleep and inability to carry out routine daily functions. What is more, victims are traumatized by the event and, sometimes, they are unable to care for loved ones, feeling numb, disconnected and unable to trust other people. The effects of child sexual abuse can include depression, anxiety and post-traumatic stress disorder (PTSD). Bashir describes the trauma effect as follows:

....the cries were all around me now, confusing and deafening. .....attacked the school.....children raped....never, not even in my darkest, blackest nightmare. Had 1 imagined that 1 would ever witness such horror...... a hallow cry of brutalized innocence......in spite of everything....the shock, the confusion, the trauma....... (pp. 210-211).

\subsection{Physical Separation from Loved Ones}

Threat of sexual violence displaces people, especially women and girls from home. This is so because they tend to hide to avoid being further raped or gang raped. This form of displacement from home deprives them and their families of their livelihoods, access to health and education. Bashir, that after the gang rape, returns home to her family who are very upset about her gang rape. This makes her father and brothers join the Zaghawa rebels. Bashir notes:

....my mother came to talk to me and 1 broke down. I confessed all....I asked her to tell my father......The war had finally come home. Before, it had been all around, but now it was in our home....it was the day of my return that my father decided to join them.....We had no choice. We had to fight or die. He shared his plans with my brothers and there was lots of fighting talk.....he, Mo and Omer would join the rebels

(pp. 230 - 232).

\subsection{Death of Loved Ones}

One of the consequences of sexual violence is the death of loved ones. Bashir lost her father to the war. Her village was attacked by The Janjaweed. "The Janjaweed are coming!". She moans:

...They are attacking the village! They are attackingthe village!..... My father grabbed me by the shoulders......Run! Take your brothers and sisters and run! To the forest! Hide! And don't come out until .....Run! Run! ....I am not going, Omer yelled... but my father's face was calm and stern as he prepares to face the enemy.......the groundwas littered with shadowy corpses, women kneeling and keening over their loved ones...... saw my brother Omer stop. His features collapsed in on themselves as he sank to his knees. I would never stop crying for my fallen father no matter how longl might live (pp. 239-244).

\section{Conclusion}

This work examined instances of sexual violence against black African Sudanese women and girls and the author comes to the conclusion that sexual violence is an outcome of a larger problem of gender inequality. She insists that in every war, women and girls become victims, as rape and, gang rape is used by each enemy camp to arrogate victory to themselves. The position of women and girls in war zones highlights the way the female body is used as a group struggle.

\section{Recommendations}

This work recommends that literary writers should expose the issues of sexual violence through their works. Literary writers should be consistent in using literature as a tool in changing behavior, attitude, beliefs and value system of the community members.

Efforts should be made to improve sexual rights of women and girls. Government should be committed to ending sexual violence against females by improving existing legislation and ensure that women who are abused sexually get justice. 
- The law should give justice to victims by ensuring that victims receive compensation in cash and kind.

- All sexual abusers should be sent to jail, with no option of fine; to serve as deterrent to would - be sexual abusers.

- Lastly, preventing sexual violence is a collective responsibility. Be your brother's keeper.

\section{References}

i. Barry, P. Beginning Theory: An Introduction to Literary and Cultural Theory. UK: Manchester University Press. 2002.

ii. Balkaya, M. Basic principles of New Historicism in the light of Stephen Greenblatt's Resonance and Wonder and Invisible Bullets. 2014.

iii. Bashir, Halima. Tears of the Desert: A memoir of Survival in Darfur. USA. One World Books.2008.

iv. Brownmiller, Susan. Against Our Will: Men, Women and Rape. USA: Simon \& Schuster Publishers. 1975. Clifford, Cassandra. "Rape as a weapon of War and its Long Effects on Victims and Society".

v. The Foreign Policy Association, New York. NY. 2008.

vi. Cohn, Carol. Women and Wars: Contested Histories, Uncertain Futures. Cambridge. U. K. Polity Press. 2010

vii. Court sentences 4 men to Death in New Delhi Gang rape Case. Available from www.cnn.com/2013/09/13/world/asia/india-gang-rape-sentence.

viii. Eight United Nations Survey on Crime Trends and the Operations of Criminal Justice Systems.

ix. Unodc.org.31 March 2005.

x. Folarin, Samson. "Journalist News report on Rape" in The Punch. 2 August 2019, p.13. Fox-Genovese, Elizabeth. Placing Women's history in History. 1982.

xi. Geside, Segi. Journalist World News Report on Rape. Nigerian Tribute. 2019, p. 33. Hanafi, Afeez. 'Journalist News report on Rape. Punch Newspaper 3 February 2019, p. 5

xii. Holmes MM et al. rape related pregnancy: estimates and descriptive characteristics from National sample of women. American Journal of Obstetrics and Gynecology, 1996, 175:320 - 324

xiii. Kaira, Gurvinder and Dinesh Bhugra. "Sexual violence against women: Understanding cross - cultural intersections." Indian Journal of Psychiatry. 2013.

xiv. Kunz, Megan Bastick,, Karin Grimm, Rahel. Sexual Violenc in armed Conflict: Global overview and implications for the security sector. Geneva. ISBN 978 - 92 - 2007.

xv. Marchbank, J and G. Letterby. Introduction to Gender: Social Science Perspectives. Pearson Education Limited. 2007.

xvi. National Crime Records Bureau (NCRB), Ministry of Home Affairs, Government of India. Page 385.

xvii. Okeoma, Chidiebube. "News report on Rape". Guardian Newspaper. 2019. p. 4-5.

xviii. Sierra Leone: rape and other forms of sexual violence against girls and women. London.

xix. Amnesty International 2000.

xx. South Africa Crime Situation. 1st April 2015. South African Police Service. The United Nations Report on Sexual Violence of Liberia War. The United Nations. 2015.

xxi. The United Nations. "Background Information on Sexual Violence used as a Tool of War." The United Nations. 2016.

xxii. The United Nations. Sexual Violence in Conflict. Office of the Special Representative of the Secretary - General on Sexual Violence in Conflict. 2017.

xxiii. Waugh, Patrica. Literary Theory and Criticism. USA. Oxford University Press. 2006.

xxiv. World Health Organisation. Violence against women - Intimate partner and sexual violence Against women. Geneva. World Health Organisation, 2011.

xxv. World Health Organisation. Female Genital Mutilation: The Prevention and the Management of the Health Complications: Policy Guidelines for nurses and midwives. WHO/ FCH/GWH/01.5. WHO, Geneva (2001). 